\title{
Policy Analysis of Budget Allocation for Disasters in Indonesia
}

Hari Apryana, Karina Rahma Nugraheni, Fatimah Wardhana

Universitas Gadjah Mada

hariapryana95@mail.ugm.ac.id

\section{Article History}

accepted 31/08/2020

approved 22/09/2020

published 28/10/2020

\begin{abstract}
As a country with high vulnerability to natural disaster, the government and communities must be prepared for disasters threats that may occur at any time. One of the most important aspects in disaster management is budgeting, which can support the effectiveness of the sustainable management. The source of disaster funding comes from the State Budget (APBN) as stated in PP. 22/2008 Article 4 paragraph (2). One of the APBN funds provided by the government is in the form of contingency funds. This study aims to analyze the implementation of disaster management preparedness funding policies and examine the problems of disaster management in the aspect of coordination among institutions. This research is a policy research conducted using a descriptive qualitative approach and literature review. The results showed that there is an overlap between budget policies and coordination among institutions in the calculation of the budget for disaster preparedness funding.
\end{abstract}

Keywords: Funding, Disaster Management, Policy

\begin{abstract}
Abstrak
Sebagai negara yang memiliki kerentanan tinggi terhadap bencana alam, pemerintah dan masyarakat dituntut untuk selalu siap menghadapi ancaman bencana alam yang dapat terjadi kapan saja. Salah satu aspek terpenting dalam manajemen bencana adalah penganggaran dana kebencanaan. Hal ini dapat mendukung efektivitas pengelolaan bencana alam yang berkelanjutan. Sumber pendanaan bencana berasal dari Anggaran Pendapatan dan Belanja Negara (APBN) yang tertuang dalam PP No. 22/2008 Pasal 4 ayat (2). Salah satu dana APBN yang disediakan oleh pemerintah berbentuk dana kontinjensi. Penelitian ini bertujuan untuk menganalisis implementasi kebijakan pendanaan kesiapsiagaan penanggulangan bencana dan mengkaji permasalahan penanggulangan bencana dalam aspek koordinasi antar lembaga. Penelitian ini merupakan penelitian kebijakan yang dilakukan dengan menggunakan pendekatan kualitatif deskriptif dan tinjauan literatur. Hasil penelitian menunjukkan bahwa terdapat tumpang tindih antara kebijakan anggaran dan koordinasi antarlembaga dalam penghitungan anggaran untuk pendanaan kesiapsiagaan bencana.

Kata kunci: Anggaran, Manajemen Bencana, Kebijakan.

Social, Humanities, and Education Studies (SHEs): Conference Series

p-ISSN 2620-

https://jurnal.uns.ac.id/shes


Indonesia termasuk dalam negara yang paling rawan terhadap bencana alam, hal ini dikarenakan posisinya yang terletak di garis khatulistiwa dan berbentuk kepulauan sehingga menimbulkan potensi tinggi untuk terjadinya berbagai jenis bencana. Data BNPB menyatakan bahwa $2 / 3$ wilayah Indonesia adalah rawan bencana. Berdasarkan Undang-undang No. 24 Tahun 2007, Indonesia memiliki 12 jenis ancaman bencana yang berisiko tinggi, yaitu: (1) gempa bumi, (2) tsunami, (3) letusan gunung berapi, (4) gerakan tanah/ tanah longsor, (5) banjir, (6) banjir bandang (7) kekeringan, (8) cuaca ekstrim, (9) gelombang ekstrim dan abrasi, (10) kebakaran hutan dan lahan , (11) epidemik dan wabah penyakit, dan (12) kegagalan teknologi. Melihat banyaknya kejadian bencana di Indonesia menyadarkan pemerintah dalam upaya penanganan bencana yang baik, agar masyarakat yang tertimpa bencana dapat mampu segera bangkit kembali. Upaya pemerintah dalam memperbaiki peanggulangan bencana dengan menerbitkan berbagai kebijakan. Dari sisi kelembagaan, pemerintah telah menetapkan lembaga penyelenggara penanggulangan bencana melalui penerbitan Keputusan Presiden No. 3 Tahun 2001 tentang Badan Koordinasi Nasional Penanggulangan Bencana dan penanganan pengungsi dan telah diubah dengan keputusan Presiden No. 111 Tahun 2001.

Tingginya potensi terjadinya bencana alam di Indonesia menyadarkan Pemerintah dan DPR untuk mengesahkan UU No 24 Tahun 2007 tentang Penanggulangan Bencana.Undang-undang ini diterbitkan karena pemerintah menyadari akan tugas dan tanggung jawabnya dalam melindungi seluruh rakyat Indonesia. Dalam penanggulangan bencana alam pemerintah Indonesia memegang peran utama, seiring adanya anggaran pemerintah yang sangat terbatas, pemerintah harus tetap bertanggung jawab untuk memastikan kerugian dan jumlah korban akibat bencana dapat tertangani dengan baik serta dapat memastikan rehabilitasi dan rekontruksi dampak bencana dapat bangkit kembali. Hubungan antara bencana alam dan tanggung jawab negara tercermin dalam alinea IV Pembukaan UUD 1945 sebagaimana hal tersebut menunjukkan adanya kewajiban negara untuk melindungi segenap masyarakat (State Legal Obligation), yaitu termasuk korban bencana.

Peraturan pemerintah tentang pendanaan dan pengelolaan bantuan bencana yaitu salah satunya dengan membuat pendanaan yaitu dana kontijensi bencana. Dana tersebut merupakan dana yang dicadangkan untuk menghadapi kemungkinan terjadinya bencana, baik bencana alam maupun bencana sosial. Dana kontijensi bencana sebagaimana dimaksud dalam Pasal 5 ayat (3) huruf a disediakan dalam APBN untuk kegiatan kesiapsiagaan pada tahap prabencana. Kontijensi adalah suatu keadaan atau situasi yang diperkirakan akan segera terjadi, tetapi mungkin juga tidak akan terjadi. Rencana kontijensi adalah suatu proses identifikasi dan penyusunan rencana yang didasarkan pada keadaan kontijensi (BNPB, 2013). Dana kontijensi diperuntukan dalam kegiatan rencana kontijensi yang lahir dari proses perencanaan kontijensi. Kurangnya kesiapsiagaan masyarakat dalam menghadapi bencana menjadikan pemerintah sadar akan pentingnya pendanaan kontijensi. Penelitian ini bertujuan untuk menganalisis bagaimana implementasi kebijakan pendanaan kesiapsiagaan penanggulangan bencana dan mengkaji problematika manajemen bencana dalam aspek koordinasi antar lembaga. Proses perencanaan kontijensi melibatkan sekelompok orang atau organisasi/lembaga yang saling bekerjasama secara berkesinambungan untuk merumuskan tindakan-tindakan yang dapat diambil oleh setiap pihak yang bersangkutan. 


\section{METODE}

Penelitian ini merupakan penelitian kebijakan (policy research) dengan menggunakan pendekatan kualitatif deskriptif dan tinjauan literatur. Penelitian kebijakan adalah prosedur penelitian ilmiah yang berusaha memperoleh pemahaman yang mendalam tentang suatu kebijakan, sehingga mendapatkan hasil yang digunakan untuk menyusun rekomendasi terkait kebijakan yang bersangkutan.

Tulisan ini merupakan bagian dari penelitian dengan tema Perspektif Problematik Manajemen Bencana di Indonesia dalam hal penyelenggaraan penanggulangan bencana.Teknik pengumpulan data yang digunakan dalam penelitian ini dengan cara tinjauan literature dari penelitian-penelitian sebelumnya dan melakukan kajian peraturan perundang-undangan terkait bencana serta peraturan terkait peraturan penganggaran. Analisis yang dilakukan adalah terhadap kebijakan alokasi anggaran dana kontijensi yang berada dalam APBN Indonesia.

\section{HASIL DAN PEMBAHASAN}

Manajemen bencana menjadi salah satu tugas dan tanggung jawab pemerintah pusat dan pemerintah daerah dengan tujuan agar bencana yang kemungkinan terjadi dapat tertangani dengan baik. Pemerintah pusat dan pemerintah daerah banyak menerbitkan kebijakan-kebijakan terkait penanganan bencana. Salah satunya dalam siklus mitigasi bencana atau pra bencana dengan menggunakan pendanaan dari APBN yang dialokasikan sebagai dana kontijensi. Dana tersebut digunakan untuk berbagai macam rencana kontijensi. Rencana kontijensi terhadap suatu bencana merupakan langkah tepat bagi masyarakat jika terjadi bencana Masyarakat harus mengetahui tindakan apa yang harus diakukan jika sewaktu-waktu terjadi bencana. Empat hal penting dalam menghadapi bencana adalah tersedianya informasi dan peta kawasan rawan bencana, kesadaran masyarakat dalam menghadapi bencana, mengetahui hal apa yang harus dihindari dan perlu dilakukan, serta mengetahui cara penyelamatan diri jika terjadi bencana sewaktu-waktu dan adanya pengaturan dan penataan kawasan rawan bencana untuk mengurangi ancaman bencana (Permenkes $\mathrm{Rl}, 2006)$.

\section{a. Perhitungan Anggaran Pendanaan Kesiapsiagaan Bencana Alam}

Dalam rangka pengganggaran untuk bencana alam, selain berpedoman pada Undang-undang nomor 17 Tahun 2003 tentang Keuangan Negara juga berpedoman pada Undang-undang 24 Tahun 2007 tentang Penanggulangan Bencana. Dalam Undang-undang tentang Penanggulangan Bencana tersebut dinyatakan dana penanggulangan bencana menjadi tanggung jawab bersama antara pemerintah pusat dan pemerintah daerah selain itu pemerintah daerah juga akan mendorong berbagai partisipasi masyarakat di dalamnya.

Penganggaran dana penanggulangan Bencana dilaksanakan oleh Pemerintah Pusat, Pemerintah Daerah, BNPB, dan atau BPBD sesuai dengan tugas pokok dan fungsinya. Berdasarkan penyelengaraan penanggulangan bencana, pemerintah pusat dan daerah memiliki tanggung jawab berupa: pengalokasian anggaran penanggulangan bencana dalam anggaran pendapatan dan belanja yang memadai dan pengalokasian anggaran penanggulangan bencana dalam bentuk dana siap pakai.

Penyediaan anggaran yang telah dirancang diharapkan mencukupi dalam menanggulangi bencana alam. Selanjutnya untuk lebih mengefektifkan maka BNPB sebagai organisasi yang dibentuk untuk menangani bencana alam di Indonesia diharapkan mampu menjalankan fungsinya yaitu sebagai pengkoordinasian pelaksanaan kegiatan penanggulangan bencana secara terencana, terarah, terpadu dan menyeluruh (Madjid, 2018).

Berbagai macam bencana alam yang terjadi seperti longsor, tsunami, banjir, gempa, dan puting beliung, seyogianya menjadi pengingat dan pembelajaran penting bagi masyarakat. Dana anggaran penanggulangan bencana yang bersumber dari 
APBN salah satunya adalah dana kontijensi. Dana kontijensi bencana sebagaimana dimaksud dalam Pasal 5 ayat (3) huruf a disediakan dalam APBN untuk kegiatan kesiapsiagaan pada tahap prabencana. Kegiatan-kegiatan pada tahap prabencana baik pada situasi tidak terjadi bencana maupun situasi terdapat potensi terjadinya bencana (kecuali untuk kegiatan kesiapsiagaan), seluruhnya menggunakan dana yang dianggarkan melalui anggaran normal APBN atau APBD, yang dialokasikan pada anggaran BNPB atau BPBD. Penggunaan dana kontijensi hanya digunakan untuk kegiatan kesiapsiagaan dalam hal terdapat potensi terjadinya bencana. Kegiatan kesiapsiagaan sendiri merupakan serangkaian kegiatan yang dilakukan untuk mengantisipasi bencana melalui pengorganisasian serta melalui langkah yang tepat guna dan berdaya guna. Dana penanggulangan bencana pada tahap prabencana dialokasikan untuk kegiatan dalam situasi: (1) tidak terjadi bencana, dan (2) terdapat potensi terjadinya bencana. Adapun penjelasan penggunaan dana adalah sebagai berikut:

1. Penggunaan dana penanggulangan bencana dalam situasi tidak terjadi bencana sebagaimana dalam Pasal 12 huruf a yang meliputi:

a. Fasilitas penyusunan rencana penanggulangan bencana

b. Program pengurangan risiko bencana

c. Pemaduan perencanaan pembangunan dengan perencanaan penanggulangan bencana

d. Penyusunan analisis risiko bencana

e. Fasilitasi pelaksanaan dan penegakan rencana tata ruang

f. Penyelenggaraan pendidikan dan pelatihan penanggulangan bencana, dan

g. Penyusunan standar teknis penanggulangan bencana.

2. Penggunaan dana penanggulngan bencana dalam situasi terdapat potensi terjadinya bencana sebagaimana dimaksud dalam Pasal 12 huruf b yang meliputi:

a. Kegiatan kesiapsiagaan

b. Pembangunan sistem peringatan dini

c. Kegiatan mitigasi bencana

Mekanisme perencanaan, penganggaran, pelaksanaan, pelaporan, dan pertanggung jawaban pada tahap pra bencana harus tetap mengikuti ketentuan yang diatur dalam Peraturan Menteri Dalam Negeri Nomor 13 Tahun 2006 Tentang Pedoman Pengelolaan Keuangan Daerah beserta peraturan perubahannya. Pada tahap prabencana, pemerintah menggunakan dana kontijensi yang dianggarkan dalam APBN dan dana lain melalui anggaran APBN atau APBD. Sedangkan pada saat tanggap darurat pemerintah dan pemerintah daerah menggunakan dana siap pakai. Dana siap pakai disediakan dalam APBN yang ditempatkan dalam anggaran BNPB dan pemerintah daerah juga dapat menyediakan dana siap pakai dalam APBD yang ditempatkan dalam anggaran BPBD. Sedangkan untuk tahap pascabencana, Pemerintah menyediakan dana bantuan sosial berpola hibah dan dana darurat. Kedua dana tersebut bersumber dari APBN yang diperuntukkan untuk kegiatan rekontruksi dan rehabilitasi pascabencana, misalnya evakuasi penduuduk, pemenuhan kebutuhan dasar berupa penampungan sementara, pemberian bantuan pangan dan non pangan, layanan kesehatan dan lain-lain, yang dilaksanakan dalam keadaan terjadinya potensi bencana. Tahapan ini termasuk dalam tahapan prabencana karena kejadian bencana belum benar-benar terjadi. Adapun tahapan pendanaan penanganan bencana seperti pada Tabel 1. 
Tabel 1. Pendanaan Penanganan Bencana

\begin{tabular}{|c|c|c|c|c|}
\hline \multicolumn{5}{|c|}{ Pendanaan Penanganan Bencana } \\
\hline Tahapan & \multicolumn{2}{|c|}{ Prabencana } & \multirow[b]{2}{*}{$\begin{array}{c}\text { Saat } \\
\text { Bencana }\end{array}$} & Pasca Bencana \\
\hline Penyelenggaraan & $\begin{array}{c}\text { Situasi } \\
\text { Terjadi } \\
\text { Bencana }\end{array}$ & $\begin{array}{c}\text { Situasi } \\
\text { Terdapat } \\
\text { Potensi } \\
\text { Bencana }\end{array}$ & & Rehabilitasi Rekontruksi \\
\hline \multirow{3}{*}{ Pendanaan } & \multicolumn{4}{|c|}{ Dana Penaggulangan Bencana dari APBN/APBD } \\
\hline & DIPA & $\begin{array}{c}\text { Dana } \\
\text { Kontijensi }\end{array}$ & $\begin{array}{l}\text { DIPA \& Dana } \\
\text { siap pakai }\end{array}$ & $\begin{array}{l}\text { DIPA \& dana bantuan } \\
\text { sosial berpola hibah }\end{array}$ \\
\hline & \multicolumn{4}{|c|}{ Dana dari masyarakat } \\
\hline
\end{tabular}

Sumber: UU No. 24 Tahun 2007

\section{b. Tumpang Tindih Kebijakan Anggaran}

Berdasarkan data Kementerian Keuangan, menurut Madjid (2018), alokasi anggaran untuk penanggulangan bencana pada tahun anggaran 2015 adalah sebagai berikut:

Tabel 2. Alokasi Anggaran Bencana dalam APBN 2015

\begin{tabular}{ccc}
\hline No. & Kementrian/Lembaga & Pagu (dalam Juta Rp) \\
\hline 1. & Kementerian Dalam Negeri & $66.950,000$ \\
2. & Kementerian Pekerjaan Umum dan & $168.207,634$ \\
3. & Perumahan Rakyat & $235.189,850$ \\
4. & Kementerian Sosial & $10.239,00$ \\
& Pementerian Koordinator Bidang & $18.078,500$ \\
5. & Kementerian Desa, Pembangunan Daerah & $986.245,600$ \\
6. & Tertinggal dan Transmigrasi & $837.529,057$ \\
7. & Badan Penangaulangan Lumpur Lapindo \\
\hline & (BPLS) & $2.322 .439,641$ \\
\hline
\end{tabular}

Menurut Tabel 2 yang telah dilampirkan di atas, tujuh instansi tersebut yang mengelola dana bencana di Indonesia. Tersebarnya alokasi anggaran maka membuat angaran tidak fokus dan sulit diukur efektifitas dan efisiensinya sehingga sulit menetapkan insitusi yang harus bertanggung jawab apabila dalam penanggulangan bencana terjadi kesalahan atau ketidakpuasan dalam masyarakat. Tingkat efisiensinya juga sulit diukur karena dana tersebar diberbagai instansi dan masing-masing institusi mengalokasikan anggaran tersebut.

Struktur organisasi yang terkait bencana tersebar pada berbagai Kementerian/Lembaga dikarenakan berbagai alasan organisasi tersebut tidak dihapus/digabungkan ketika pemerintah Indonesia membentuk organisasi baru yaitu Badan Nasional Penanggulangan Bencana. Terbentuk BNPB menjadikan tugas pokok dan fungsi terkait bencana alam di organisasi yang lain idealnya dihapuskan dan dipindahkan ke BNPB sehingga tidak terjadi tumpang tindih pengalokasian anggaran.

\section{SIMPULAN}

Tersebarnya alokasi anggaran di beberapa lembaga/instansi membuat anggaran tidak fokus dan sulit diukur efektifitas dan efisiensi program penanggulangan bencananya. Hal ini mempersulit penetapan insitusi yang harus bertanggung jawab 
apabila dalam penanggulangan bencana terjadi kesalahan atau ketidakpuasan dalam masyarakat. Akan lebih baik apabila salah satu lembaga seperti BNPB yang memiliki fungsi koordinasi mengambil alih pengalokasian anggaran sehingga tidak terjadi tumpeng tindih pengalokasian anggaran.

\section{DAFTAR PUSTAKA}

BNPB. (2013). Rencana Kontijensi Mengahdapi Ancaman Bencana Letusan Gunung Api Rokatenda Kabupaten Sikka dan Kabupaten Ende Provinsi Nusa Tenggara Timur. Pemerintah Kabupaten Sikka dan Kabupaten Ende.

Madjid, N. C. (2018). Analisis Metode Perhitungan dan Alokasi Anggaran Bencana Alam. Simposium Nasional Keuangan Negara.

Pasal 1 angka 4 Peraturan Pemerintah Nomor 22 Tahun 2008 Tentang Pendanaan dan Pengelolaan Bantuan Bencana.

Pemernekes RI. (2006). Pedoman Umum Mitigasi Bencana. Jakarta: Mentri dalam Negeri.

Peraturan Menteri Dalam Negeri Nomor 13 Tahun 2006 Tentang Pedoman Pengelolaan Keuangan Daerah

Undang-Undang Republik Indonesia Nomor 24 Tahun 2007 Tentang Penanggulangan Bencana

Undang-undang nomor 17 Tahun 2003 Tentang Keuangan Negara

KEPPRES No. 111 Tahun 2001 Tentang Perubahan Atas Keputusan Presiden Nomor 3 Tahun 2001 Tentang Badan Koordinasi Nasional Penanggulangan Bencana Dan Penanganan Pengungsi. 